5. Rede Brasileira de Pesquisas Neonatais. Uso antenatal de corticosteróide e evolução clínica de recém-nascidos pré-termos. J Pediatr (Rio J). 2004;80:277-84.

6. Jones G, Steketee RW, Black RE, Bhutta ZA, Morris SS. How many child deaths con we prevent this year? Lancet. 2003;362: 65-71.

7. Matijasevich A, Barros FC, Forteza C, Diaz-Rossello JL. Atenção à saúde de crianças de muito baixo peso ao nascer de Montevidéu, Uruguai: comparação entre os setores públicos e privado. J Pediatr (Rio J). 2001;77:313-20.
8. Krauss Silva $L$, Pinheiro da Costa $T$, Reis $A F$, Iamada NO, Azevedo AP, Albuquerque CP. Avaliação da qualidade da assistência hospitalar obstétrica: uso de corticóides no trabalho de parto prematuro. Cad Saúde Publica. 1999;15:817-29.

9. Leone CR, Sadeck LSR, Vaz FC, Almeida MFB, Draque CM, Guinsburg R, et al. Brazilian Neonatal Research Network (BNRN): Very Low Birth Weight (VLBW) infant morbidity and mortality. Pediatr Res. 2001;49:405A.

\title{
When should we start phototherapy in preterm newborn infants?
}

\author{
Maria Fernanda B. de Almeida*
}

nconjugated hyperbilirubinemia is commonly observed in all preterm infants, especially in very low birthweight newborns. Studies show that the large amount of short-lived red blood cells, and the increase in enterohepatic circulation of bilirubin and the deficient hepatic conjugation of bilirubin are the most important physiological conditions that cause hyperbilirubinemia. In addition, the delayed implementation of enteral nutrition, which is common in critically ill preterm newborns, may restrict intestinal blood flow and enhance the enterohepatic reuptake of bilirubin. Therefore, due to erythrocyte, hepatic and gastrointestinal immaturity, "physiological" jaundice is more intense than that observed in full-term newborns. The total bilirubin concentration ranges between 10 and $12 \mathrm{mg} /$ $\mathrm{dl}$ on the fifth day of life and may not reach normal values until the end of the first month. ${ }^{1}$

One of the most frequent specific causes concerns blood extravasation caused either by extensive hematomas in upper and lower limbs due to birth trauma or by intraventricular hemorrhage, especially in those infants aged less than 34 weeks. However, despite the proper investigation into unconjugated hyperbilirubinemia based on the history and outcome of preterm newborns, most cases do not have a clear etiology. On top of that, patients submitted to intensive care may show association of predisposing factors for penetration of bilirubin into the brain, such as hypoxemia, acidosis, hypothermia, hypoalbuminemia, hypercapnia, among others. ${ }^{2}$

* Associate professor, Universidade Federal de São Paulo (UNIFESP), São Paulo, SP, Brazil.
Although unconjugated hyperbilirubinemia is almost universally found in preterm newborns, several studies published in the 1990s do not show a causal relationship between hyperbilirubinemia within controlled limits (total bilirubin that is on average lower than $15 \mathrm{mg} / \mathrm{dl}$ ) and neurological, hearing, visual, speech and developmental disorders. ${ }^{3-4}$

Nevertheless, in 2001, Sugama et al. ${ }^{5}$ questioned the rare occurrence of bilirubin encephalopathy in preterm newborns after they detected kernicterus in two patients at 31 and 34 weeks of gestational age, respectively, with bilirubin levels between 13.1 and $14.7 \mathrm{mg} / \mathrm{dl}$; none of the patients had symptoms that could suggest the disease in the neonatal period. The first case revealed athetoid cerebral palsy at the age of three years, and the second patient could not hold his head up and had hypotonia. Magnetic resonance revealed findings compatible with bilirubin encephalopathy, resulting in the hypothesis that low bilirubin levels may cause brain injury in preterm newborns and that the risk for kernicterus is difficult to be determined in the neonatal period.

Thus, the risks of brain injury associated with hyperbilirubinemia in preterm newborns and the quantification of this risk have been widely discussed. One of the greatest challenges is concerned with the determination of tolerable levels of unconjugated bilirubin for the prevention of bilirubin encephalopathy in this group of patients. Although most of these patients, especially those weighing less than $1,500 \mathrm{~g}$, are submitted to phototherapy, several questions need to be answered: When should it be initiated? What bilirubin levels determine the use of phototherapy? What is the maximum bilirubin 
level to consider phototherapy failure and indicate exchange transfusion?

Phototherapy can be initiated between 12 and 24 hours of life, regardless of the bilirubin level, and can be prophylactic, early or aggressive. Phototherapy that takes into account bilirubin levels can be therapeutic, delayed or conservative. ${ }^{6}$

Hansen, in $1996,{ }^{7}$ in an attempt to document and compare the several types of treatment for neonatal jaundice in several countries, sent a questionnaire to neonatologists of several neonatal ICUs in Europe, North America, Africa and Asia. Of 218 questionnaires, 108 were filled out and returned, of which 53 (49\%) showed the use of prophylactic phototherapy. In newborns weighing $500 \mathrm{~g}$, the total bilirubin concentration determining initiation of therapy ranged from 3 to $10 \mathrm{mg} / \mathrm{dl}$ in the first 72 hours of life. In newborns weighing $1500 \mathrm{~g}$, the minimum value for indication of phototherapy varied between 5 and $7 \mathrm{mg} / \mathrm{dl}$, whereas the maximum value ranged from 12 to $14 \mathrm{mg} / \mathrm{dl}$ in the first 72 hours of life. Moreover, in 92 neonatal units (85\%), it was the patient's clinical status that determined the moment for implementation of phototherapy.

In this context, the controlled and randomized clinical trial by Leite $\&$ Facchini ${ }^{8}$ assesses early and late initiation of phototherapy in newborns weighing less than $2000 \mathrm{~g}$ without hemolytic disease due to blood incompatibility. The authors measured the concentration of transcutaneous bilirubin on a daily basis and concluded that early treatment, implemented at 12 hours of life, is safer than late treatment (when bilirubin level is equal to or greater than $8 \mathrm{md} / \mathrm{dl}$ ) because it maintains bilirubin levels below $10 \mathrm{mg} / \mathrm{dl}$.

An important aspect of this study is the average spectral irradiance of $14 \mu \mathrm{W} / \mathrm{cm}^{2} / \mathrm{nm}$, obtained with special blue lights (considered the gold standard). Thus, irradiance was appropriate, ideal and greater than that used in our setting, where a value around $4 \mu \mathrm{W} / \mathrm{cm}^{2} / \mathrm{nm}^{9}$ has been employed, as this is the minimum limit for conventional phototherapy to be effective.

With regard to the patient population, special attention should be given to newborns with a birthweight lower than $1,000 \mathrm{~g}$ (four patients in early treatment and eight in prophylactic treatment) among 81 analyzed patients. This number is small and does not allow for conclusions, as admitted by the authors. The use of early phototherapy at 12 hours of life in newborns weighing between 1,501 and $2,000 \mathrm{~g}$ is also of note. In this weight category, the initiation of phototherapy often occurs when bilirubin levels range from 8 to $12 \mathrm{mg} / \mathrm{dl}$.

The authors who advocate prophylactic phototherapy believe that if it is implemented early, it may prevent larger increases in serum bilirubin concentration, which would reduce the need for exchange transfusion. On the other hand, the researchers who use therapeutic phototherapy when unconjugated hyperbilirubinemia has already been established, do so based on the idea that the efficiency of phototherapy increases if it is initiated when bilirubin concentration is high. In addition, even though bilirubin is considered a neurotoxic agent, there is some evidence that benign neonatal bilirubin concentration has a physiological function. This makes us wonder about the actual necessity to prevent and/or treat physiologic hyperbilirubinemia completely in very low birthweight newborns, who are quite vulnerable to oxidative injury and minimal hepatic function. ${ }^{1}$ However, researchers who defend therapeutic phototherapy do not share a common agreement on the serum bilirubin concentration that should be used for indication of phototherapy: 5 to 8 $\mathrm{mg} / \mathrm{dl}^{6}$ and 8 to $12 \mathrm{mg} / \mathrm{dl}^{1}$

Until 2002,10 the American Academy of Pediatrics considered that there was a paucity of properly designed studies and observational data on low birthweight newborns without hemolytic disease, which hinders the development of a specific treatment routine. Therefore, a more aggressive treatment, such as exchange transfusion with total bilirubin levels of $10 \mathrm{mg} / \mathrm{dl}$, or a more conservative treatment with bilirubin concentrations between 15 and $20 \mathrm{mg} / \mathrm{dl}$ are acceptable for preterm newborns.

Based on these considerations, a special interest in the outcome of newborns submitted to two phototherapy regimens has been aroused. The recent study by Jangaard et al. ${ }^{11}$ published in 2004, assessed 95 newborns weighing less than $1,500 \mathrm{~g}$ at birth submitted to prophylactic phototherapy initiated at 12 hours of life or therapeutic phototherapy when total bilirubin concentration was equal to or greater than $8.8 \mathrm{mg} / \mathrm{dl}$. Of 87 survivors, 82 had their neurological behavior followed up to 12 months and 75 up to 18 months of corrected gestational age. Cerebral palsy and death were more frequent in the group that received therapeutic phototherapy. The authors concluded that low bilirubin levels may be associated with a better prognosis in these newborns.

Given the lack of information on which is the best therapeutic approach to hyperbilirubinemia in preterm newborns, a prospective and randomized study has been underway with the aim of comparing phototherapy initiated between 12 and 24 hours of life, regardless of bilirubin concentration, and phototherapy indicated when the total bilirubin concentration is equal to or greater than $8 \mathrm{mg} / \mathrm{dl}$ in newborns with birthweight between 501 and $750 \mathrm{~g}$ and equal to or greater than $10 \mathrm{mg} / \mathrm{dl}$ in those weighing between 751 and 1,000 g. Exchange transfusion has been indicated if bilirubin levels are equal to or greater than 13 $\mathrm{mg} / \mathrm{dl}$ and $15 \mathrm{mg} / \mathrm{dl}$, in the first and second groups, respectively. The results of this study may provide important information about the risks and benefits of phototherapy in these patients, since neurological development will be evaluated at 18 and 22 months of corrected gestational age. ${ }^{6}$

The management of very low birthweight newborns with high levels of bilirubin will continue to be mainly based on epidemiological evidence. Prevention of kernicterus in preterm infants is still an unsolved problem, and what Lucey said in 1982 still applies today: "There is no level, there probably never was a level, nor will there be a level" of bilirubin to exclude the disease. ${ }^{12}$ 


\section{References}

1. Cashore WJ. Bilirubin and jaundice in the micropremie. Clin Perinatol. 2000;27:171-9.

2. Watchko JF, Maisels MJ. Jaundice in low birthweight infants pathobiology and outcome. Arch Dis Child Fetal Neonatal. 2003;88:455-8.

3. Scheidt PC, Bryla DA, Nelson KB, Hoffman HJ. Phototherapy for neonatal hyperbilirubinemia: six-year follow-up of the National Institute of Child and Human Development clinical trial. Pediatrics. 1990;85:455-62.

4. van de Bor $M$, Ens-Dokkum $M$, Schreuder AM, Veen S, Brand R, Verloove-Vanhorick SP. Hyperbilirubinemia in low birth weight infants and outcome at 5 years of age. Pediatrics. 1992; 89:359-64.

5. Sugama S, Soeda A, Eto Y. Magnetic resonance imaging in three children with kernicterus. Pediatr Neurol. 2001;25:328-31.

6. Maisels MJ, Watchko JF. Treatment of jaundice in low birth weight infants. Arch Dis Child Fetal Neonatal. 2003;88:459-63.
7. Hansen TWR. Therapeutic approaches to neonatal jaundice: an international survey. Clin Pediatr. 1996;35:309-16.

8. Leite MGC, Facchini FP. Avaliação de dois esquemas de indicação de fototerapia em recém-nascidos com peso menor que 2.000 g. J Pediatr (Rio J). 2004;80:285-90.

9. De Carvalho M, Lopes JMA. Phototherapy units in Brazil: are they effective? J Perinat Med. 1995;23:315-9.

10. American Academy of Pediatrics and American College of Obstetricians and Gynecologists. Guidelines for perinatal care. 5th ed. Elk Grove Village: American Academy of Pediatrics; 2002.

11. Jangaard A, Cake HA, McHugh SM, Vincer MJ. Neurodevelopment outcomes at 18-months corrected age in infants weighting < $1500 \mathrm{~g}$ enrolled in a randomized trial of aggressive versus conservative phototherapy. Pediatr Res. 2004;55:418A.

12. Lucey JF. Bilirubin and brain damage: a real mess. Pediatrics. 1982;69:381-2. 